\title{
Issues and Challenges for Integrated Solid Waste Management in Saharanpur City
}

\author{
Arvind Kumar Arora \\ School of Agriculture \& Environmental Sciences, \\ Shobhit University, Gangoh, Saharanpur \\ Email: arvindarora.sre@gmail.com \\ Dr. Mohd. Vaseem \\ Asst. Prof., School of Agriculture \& Environmental Sciences, \\ Shobhit University, Gangoh, Saharanpur
}

\begin{abstract}
Solid waste management usually refers to the collection, transportation, recycling, resources recovery, composting, and disposal of municipal solid waste, municipal solid waste is defined to include refuse from households, non-hazardous solid wastage from industrial and commercial establishments, refuse from institutions market waste, yard waste, and street sweeping, etc. Management of municipals solid waste involves the development of an instigated into the impact of waste generation, collection, transportation, and disposal methods adopted by a society on the environment and adoption of new methods to reduce this impact.
\end{abstract}

Keywords: Solid waste Management, Integrated SWM, SMC, Composting, Recycle, Processing.
Reference to this paper

should be made as follows:

Received: 05.08.2020

Approved: 29.09.2020

Arvind K. Arora

Dr. Mohd. Vaseem

Issues and Challenges for Integrated Solid

Waste Management in Saharanpur City

Article No. 25

RJPSS Sept. 2020,

Vol. XLV No. 2,

pp. 216-220

Online available at:

https://anubooks.com/

rjpss-2020-vol-xlv-no-2/

https://doi.org/

10.31995

rjpss.2020.v45i01.025 
RJPSS Sept. 2020 Vol. XLV No.2, ISSN: (P)0258-1701 (e)2454-3403 Impact Factor: 7.717

https://doi.org/10.31995/rjpss.2020.v45i01.025

\section{INTRODUCTION:}

Saharanpur is a famous wood carving city which is situated in the northwestern part of Uttar Pradesh. Paon Dhoni river and Dhamola river flows across the Centre part of the city. Saharanpur is situated at $29^{\circ}, 90^{\circ}$ north, and $77^{\circ}, 32^{\circ}$ east, having an average height above sea level of approximately $90 \mathrm{ft}$. Saharanpur Nagar Nigam has 70 wards with 705478 population as per census 2011 .

The socio-economic development and environmental degradation have become inseparable entities of modern lifestyle with newly invented plastics alloys, agrochemicals, and other materials that provide comfort and means of coverage in our daily life have been responsible for the generation of a variety of waste.

But still, the waste collection and disposal mechanism of the Urban local bodies continues to be equally alarming give in the current state of affairs it is estimated that only between $30-60 \%$ (rouse, 2006) of the municipal solid waste generated in Indian cities is actually collected and disposed of by the ULBS. Another study (median, et.al, 2002) mentions a collection rate of just 50\% in Urban India, due to this lack of collection, our cities are never free from Garbage. Even after the daily sanitation practice of ULb's lot of garbage exists in the various places of our cities. Out of this collected waste only a fraction i.e. $7 \%$ to $10 \%$ is recycled, the generation of waste per capita increases from 1 to $1.33 \%$ per year. More than $90 \%$ of the solid waste is disposed of indiscriminately in Unsanitary and poorly located landfills.

Due to a lack of awareness and an Uncaring attitude on part of citizens, solid waste is being dumped in the drain that generally results in blockage of drains.

A scientifically designed solid waste management system and related techniques including approved methods of collection and transportation, recycling, etc. is the need concerning the environment and good Urban planning for good living aspects.

\section{EXISTING SWM SCENARIO:}

As the old popular method of Garbage collection, Saharanpur municipal corporation started waste management with open community bins in different localities. These bins consisted of bottomless circular concrete rings and have mixed waste dumped into them by its citizens. After sometime later it changed to iron covered bins. When it was full, it was collected manually by municipal workers and transported in dome-shaped MSW trucks to a landfill where crude dumping was done, Saharanpur Municipal corporation is dumping waste in an Unscientific manner at a crude dumping site. Approx. 140000 households in Saharanpur approx.. 300 MT tons of waste generated daily but there is no any type of disposal of garbage 
Arvind Kumar Arora, Dr. Mohd. Vaseem

method is present in municipal corporation Saharanpur. Apart from the private waste

collectors and few NGOs, SMC collects the waste from the dumpsite, streets, etc. in this process 80 vehicles and approx. 250 persons engaged in the process.

\section{Issues with Current SWM practices of Saharanpur Municipal Corporation:}

1- Segregation of recyclable waste at source is not practiced in the city, people prefer to dispose of the waste as and where its generated.

2 - Except few wards of the city there is no proper system of the door to door collection of waste. Community bin facility is not provided in the deep colony areas, due to the lack of these facilities people throw the waste on the vacant spaces, open plots, street corners and drains.

3- At random placement of bins and big storage open containers invite stray animals and create Unhygienic conditions.

4- No arrangements for primary collection from hotels, restaurants, and Banquets, a large quantity of generation of waste dumped in nearby bin's and containers, and due to these bins are usually overflowing.

5- Vegetable, fruit, meat, and fish markets do not have adequate waste storage containers.

6 - At least $30 \%$ of the city populations reside in slums and undeveloped areas without any facility of garbage collection.

7- The transportation of waste is done in open trucks and trolleys in day time at busy route's causing nuisance and environmental degradation.

8- The city does not have a sanitary landfill. The waste generated in the city is presently being disposed of in an unscientific manager.

9- In Saharanpur activities and operations of the wood carving industry produce a large amount of waste in the form of wooden solid waste. Some amount of wooden waste lies on the sand, drainage systems and wooden dust flows in the air and causes various impacts on the environment.

10- In Saharanpur two large industry i.e. ITC cigarette factory and Star Paper Mills and few cardboard mills and two define industrial areas produce residual waste and other related waste, SMC has no planning of disposal for these types of waste.

11- A large number of dairies and animals are situated in the highly built-up areas due to this animal's dung flows in the drainage system and choke the drains.

12-In Saharanpur large number of markets produce daily 'e' waste, another category of waste is slaughter waste as well as construction and demolition waste and Junkyard, scrap waste but SMC has no management plan for this category of waste. 
RJPSS Sept. 2020 Vol. XLV No.2, ISSN: (P)0258-1701 (e)2454-3403 Impact Factor: 7.717

https://doi.org/10.31995/rjpss.2020.v45i01.025

13- No major effort by the Saharanpur Municipal corporation has been made to initiate composting, recycling, or any other useful ways to deal with the solid waste. Possibilities of Integrated SWM in Saharanpur city:

Saharanpur city or Saharanpur Municipal Corporation area is 73.72 sq. Km. with a population density of 15094 persons per $\mathrm{Km} 2$ with the $54.79 \%$ growth in population between the census 2001 to 2011, In India, we have so many informal practices of works as well as in the field of SWM, some rag pickers are participating in this in every city. A large quantity of solid waste segregated for recycling by these rag pickers. In Saharanpur rag pickers, collect items based upon its recyclable demand including plastic, paper, iron, cloth, animal bones, leathers, and other allied articles.

\section{OPTIONS FOR SWM:}

1. Saharanpur Municipal Corporation opts Incineration based waste to energy technology because Saharanpur has a large number of wood carving industries and large No's of private nursing homes but this technology costs a heavy amount for operation and maintenance and it is not successful for wet waste.

2. Anaerobic Digestion or Bio methanation, this could be a better option than the incineration and it's still more capital intensive compared to composting and landfill but it is not a better option for the mixed type of waste.

3. A Sanitary landfill might become a viable option but it was a high initial cost for design and construction.

4. Palletization is another option but it is not operational in the rainy season because wet waste increases the cost of drying.

5. Composting of organic content high in the waste it's a viable method.

6. Recycling of all possible waste matter is desirable. Sorting and segregation is the most factor for its reuse options in various activities.

7. There would be no requirement of community waste containers in residential areas if the waste could be collected from the source. In the area of commercial activity, this would continue to be required.

8. Designation transfer, stations in each sanitary ward would be required.

9. SMC could give organic waste to a private entrepreneur for compost making and selling.

10. The inert debris is usually lying on roadsides and should be directly taken by the SMC trucks from there and transported to a site for depositing insert debris. A lot of portions of inert debris are recyclable and the option of 

is a good solution to cut down the quantity that will go into dumping ground.

\section{CONCLUSIONS:}

One of the biggest challenges in the implementation of SWM programs is the lack of participation of the people, who are primary stakeholders and beneficiaries of the program. The Governmental functionary is hindered by rigid and complex systems -financial, administrative, contracting, etc. to make the solid waste management program successful. Some key factors are-

(1) Private waste collector

(2) Source segregation

(3) Waste reduction

(4) $100 \%$ waste collection

(5) Processing of waste.

An integrated system could help solve the seemingly intractable problem of municipal solid waste management in an economically viable, socially describe, and environmentally sound manner and also create jobs, reduce poverty, extend the collection and improve final disposal of wastes and current practices that contribute to waste reduction, recovering reuse and recycling can be integrated into the present systems.

\section{REFERENCES}

1. CPCB 2000, Management of MPL solid waste, CPCB publications New Delhi.

2. Medina, M, et, al 2002 Globalization, Development, and Municipal Solid waste mgmt. in third world cities, www.gdnet.org. 12-4-15

3. ROUSE, J, 2006, Involving the informal sector in his proved solid waste management, www.cwg.net.

4. SWACH SURVEKSHAN 2019 SMC.

5. CENSUS- 2011

6. Master Plan 2001-2021 Saharanpur development authority.

7. Municipal Solid Waste Management Handling rule- 2016 Rule 22.

8. CPHEEO Manual, Jan 2000, World Bank 1994. 